\title{
Ocean acidification increases the sensitivity of and variability in physiological responses of an intertidal limpet to thermal stress
}

\author{
Jie Wang ${ }^{1}$, Bayden D. Russell ${ }^{2}$, Meng-Wen Ding ${ }^{1}$, and Yun-Wei Dong ${ }^{1,3}$ \\ ${ }^{1}$ State Key Laboratory of Marine Environmental Science, College of Ocean and Earth Sciences, \\ Xiamen University, Xiamen 361000, China \\ ${ }^{2}$ The Swire Institute of Marine Science and School of Biological Sciences, The University of Hong Kong, \\ Hong Kong SAR, 999077, China \\ ${ }^{3}$ Fujian Collaborative Innovation Center for Exploitation and Utilization of Marine Biological Resources, \\ Xiamen University, Xiamen 361102, China
}

Correspondence: Yun-Wei Dong (dongyw@xmu.edu.cn)

Received: 14 February 2017 - Discussion started: 7 March 2017

Revised: 14 April 2018 - Accepted: 22 April 2018 - Published: 9 May 2018

\begin{abstract}
Understanding physiological responses of organisms to warming and ocean acidification is the first step towards predicting the potential population- and communitylevel ecological impacts of these stressors. Increasingly, physiological plasticity is being recognized as important for organisms to adapt to the changing microclimates. Here, we evaluate the importance of physiological plasticity for coping with ocean acidification and elevated temperature, and its variability among individuals, of the intertidal limpet $\mathrm{Cel}$ lana toreuma from the same population in Xiamen. Limpets were collected from shaded mid-intertidal rock surfaces. They were acclimated under combinations of different $p \mathrm{CO}_{2}$ concentrations (400 and $1000 \mathrm{ppm}$, corresponding to a $\mathrm{pH}$ of 8.1 and 7.8) and temperatures $\left(20\right.$ and $\left.24^{\circ} \mathrm{C}\right)$ in a shortterm period ( 7 days), with the control conditions $\left(20^{\circ} \mathrm{C}\right.$ and $400 \mathrm{ppm}$ ) representing the average annual temperature and present-day $p \mathrm{CO}_{2}$ level at the collection site. Heart rates (as a proxy for metabolic performance) and expression of genes encoding inducible and constitutive heat-shock proteins ( $h s p 70$ and $h s c 70)$ at different heat-shock temperatures $\left(26,30,34\right.$, and $\left.38^{\circ} \mathrm{C}\right)$ were measured. Hsp70 and Hsc70 play important roles in protecting cells from heat stresses, but have different expression patterns, with Hsp70 significantly increased in expression during stress and Hsc70 constitutively expressed and only mildly induced during stress. Analysis of heart rate showed significantly higher temperature coefficients $\left(Q_{10}\right.$ rates) for limpets at $20^{\circ} \mathrm{C}$ than at $24^{\circ} \mathrm{C}$ and post-acclimation thermal sensitivity of limpets at
\end{abstract}

$400 \mathrm{ppm}$ was lower than at $1000 \mathrm{ppm}$. Expression of $h s p 70$ linearly increased with the increasing heat-shock temperatures, with the largest slope occurring in limpets acclimated under a future scenario $\left(24^{\circ} \mathrm{C}\right.$ and $\left.1000 \mathrm{ppm} p \mathrm{CO}_{2}\right)$. These results suggested that limpets showed increased sensitivity and stress response under future conditions. Furthermore, the increased variation in physiological response under the future scenario indicated that some individuals have higher physiological plasticity to cope with these conditions. While shortterm acclimation to reduced $\mathrm{pH}$ seawater decreases the ability of partial individuals against thermal stress, physiological plasticity and variability seem to be crucial in allowing some intertidal animals to survive in a rapidly changing environment.

\section{Introduction}

Benthic organisms living in the intertidal zone will be exposed to increasingly variable and extreme environmental conditions, such as temperature, oxygen, and $\mathrm{CO}_{2}$, due to climatic change (IPCC, 2013; Kwiatkowski et al., 2016). These highly fluctuating environmental variables can significantly affect the physiological performance of coastal species (Helmuth et al., 2006; Hofmann and Todgham, 2010; Somero, 2012; Widdicombe and Spicer, 2008). Therefore, understanding the interaction of multiple environmental stressors on physiological performance is crucial for predict- 
ing the consequences of environmental change on ecosystems (Deutsch et al., 2015). For example, salinity fluctuations coupled with high temperatures during emersion can have both sublethal physiological effects and lethal effects on intertidal mollusks (Dong et al., 2014; Firth and Williams, 2009). Although ocean acidification can increase the growth of organisms in some cases (e.g., Gooding et al., 2009), there is increasing evidence that decreased $\mathrm{pH}$ exacerbates global warming, and interactions of ocean acidification and warming reduce resistance of an organism to environmental change (Munday et al., 2009) and subsequently affect population dynamics (Fabry et al., 2008; Hoegh-Guldberg et al., 2007; Kroeker et al., 2013; Rodolfo-Metalpa et al., 2011).

In the face of a changing environment, organisms can respond in three ways: exhibit shifts in distributional ranges (Parmesan and Yohe, 2003), develop adaptive changes (Hoffmann and Sgro, 2011), or perish (Fabricius et al., 2011). Prior to mortality or range shifts, environmental changes can often drive physiological adaptation or the evolution of phenotypic plasticity (Chevin et al., 2010; Sanford and Kelly, 2011). However, warming and ocean acidification are not unidirectional, but rather combined with rapid fluctuations on daily to seasonal and decadal timescales. Thus, the changing environment often does not provide clear signals to drive strong directional selection of traits, meaning that, usually, physiological plasticity is the more important factor in acclimation to changing environmental conditions (Hoffmann and Sgro, 2011; Pörtner et al., 2012; Somero et al., 2012). In a recent meta-analysis, Seebacher et al. (2015) demonstrated that acclimation to higher temperatures decreased the sensitivity to increased temperature in both freshwater and marine animals. While this response suggests that acclimation could reduce the impact of warming on organisms, the responses were only tested for shifts in mean temperature. Furthermore, organisms inhabiting variable environments, such as the intertidal zone, will be exposed to increasing extremes in temperature concomitant with increasing $p \mathrm{CO}_{2}$, or ocean acidification, in the future. While ocean acidification has been suggested to increase the sensitivity of organisms to warming (Byrne and Przeslawski, 2013; Byrne, 2011; Kroeker et al., 2013), physiological plasticity and variation in responses may provide the basis for populations to survive.

Physiological variation, or plasticity, within a population is important for adapting to local microclimate and for evolution (Dong et al., 2017; Oleksiak et al., 2002; Prosser, 1955). For example, different color morphs of the gastropod Littorina saxatilis have enhanced physiological performance, which leads to increased survival under extreme conditions, indicating physiological differences may provide a selective advantage for those color morphs under an extremely fluctuating salinity and temperature regime in estuaries (Sokolova and Berger, 2000). For the limpet Cellana toreuma, highly variable expressions of genes related to stress responses and energy metabolism are important for surviving the harsh environment on subtropical rocky shores (Dong et al., 2014).
Heart rate, as a measure of cardiac activity, is a useful indicator for indicating physiological response to stress in mollusks (Dong and Williams, 2011; Xing et al., 2016). Animals exhibit a stable basal heart rate under conditions which are not thermally stressful, and heart rate increases and reaches a peak followed by a sudden decrease with temperature rising (Braby and Somero, 2006; Dong and Williams, 2011). The temperature at which a sharp discontinuity in slope occurs in an Arrhenius plot (i.e., Arrhenius breakpoint temperature, ABT) can represent the limit of metabolic functioning of animals (Nickerson et al., 1989; Somero, 2002). At the molecular level, expression of heat-shock proteins (HSPs) and $h s p$ genes is induced above a certain temperature, reaches maximum, and finally ceases in response to heat shock (Han et al., 2013; Miller et al., 2009). Upregulation of HSPs and $h s p$ genes is an energy-consuming mechanism for defense against thermal stress (Somero et al., 2016). As a commonly used biomarker, the Hsp70 multigenic family includes two proteins with divergent expression patterns (inducible Hsp70 and constitutive Hsc70). The inducible Hsp70 significantly increases in expression when animals are exposed to stressors and plays a role in maintaining protein stability (Feder and Hofmann, 1999); conversely, the constitutive Hsc70, which is transcribed continuously and may be mildly induced during stress, takes part in folding and repairing of denatured proteins (Dong et al., 2015) and plays a role in the formation of mitotic structures (Sconzo et al., 1999). Some studies have shown coordinated heart rate and expression of genes encoding to HSPs in response to elevated temperature (Han et al., 2013; Prusina et al., 2014). However, little is known about the patterns of heart rate and expression of $h s p$ genes for coping with combined warming and ocean acidification.

The limpet $C$. toreuma is a keystone species on rocky shores in the western Pacific (Dong et al., 2012), occupying the mid-low intertidal zones (Morton and Morton, 1983). This species is a gonochoric and broadcast spawner, whose embryos develop into planktonic trochophore larvae and later into juvenile veligers before becoming fully grown adults (Ruppert et al., 2004). As a common calcifier inhabiting coastal ecosystems, C. toreuma plays an important ecological role in food chains (Ding et al., 2018), grazing on biofilm and being an important food source for other species (e.g., crabs, seabirds, and sea stars). Therefore, this species is a key organism for studying the relationship between physiological response to thermal stress and ocean acidification in a highly variable environment on the shore.

Under the impact of subtropical high-pressure systems, Xiamen $\left(118^{\circ} 14^{\prime} \mathrm{E}, 24^{\circ} 42^{\prime} \mathrm{N}\right)$ is one of the hottest areas in China (Dong et al., 2017). The coastal seawater of this area is experiencing rapid temperature rise and acidification (Bao and Ren, 2014). The sea surface temperature in Xiamen coastal water has increased a total of $1{ }^{\circ} \mathrm{C}$ since 1960 , and is rising at a mean annual rate of $0.02^{\circ} \mathrm{C}$ (Yan et al., 2016). The annual $\mathrm{pH}$ values of seawater in Xiamen Bay have declined 
by $0.2 \mathrm{pH}$ units from 8.05 in 1986 to 7.85 in 2012, a trend which is predicted to continue based on simulations (Cai et al., 2016).

Here, we investigated the importance of physiological plasticity (based on the measurement of post-acclimation temperature sensitivity; see Seebacher et al., 2015) and variability (based on coefficient of variation) for C. toreuma to cope with ocean acidification and elevated temperatures by quantifying heart rates (as a proxy of metabolic performance) and expression of genes encoding inducible and constitutive heat-shock proteins (Hsp70 and Hsc70) after shortterm acclimation in different $p \mathrm{CO}_{2}$ concentrations (400 and $1000 \mathrm{ppm})$ and temperatures $\left(20\right.$ and $\left.24^{\circ} \mathrm{C}\right)$. We hypothesize that (1) limpets will show increased thermal sensitivity of metabolism and stress responses under elevated $p \mathrm{CO}_{2}$ and temperatures and (2) short-term acclimation at high temperature and $p \mathrm{CO}_{2}$ will cause higher inter-individual physiological variation. Our study, by measuring both heart rate and heat-shock protein gene expression, provides novel information concerning the combined effects of increased temperature and $p \mathrm{CO}_{2}$ on stress response, energy consumption, and physiological plasticity in intertidal invertebrates, potentially providing predications of ecological impacts of the future environmental changes.

\section{Material and methods}

\subsection{Limpet collection and experiment treatments}

Samples were collected from shaded rock surfaces at midtidal level in Xiamen during a falling high tide in July (in situ temperature: $30.8 \pm 0.8^{\circ} \mathrm{C}$ ). The sampling ensured that all limpets have similar thermal history, given the possible impacts from microclimate (Dong et al., 2017; Lathlean and Seuront, 2014). They were transported to the State Key Laboratory of Marine Environmental Science, Xiamen University, China, within $2 \mathrm{~h}$. Limpets were first allowed to recover at $20^{\circ} \mathrm{C}$ for 3 days with a tidal cycle of approximately $6 \mathrm{~h}$ of immersion and $6 \mathrm{~h}$ of emersion. These limpets were randomly allocated into one of four treatments and temporally acclimated in different $p \mathrm{CO}_{2}$ concentrations and temperatures (LTLC, low temperature and low $\mathrm{CO}_{2}$, $20^{\circ} \mathrm{C}+400 \mathrm{ppm}$, as a control treatment; LTHC, low temperature and high $\mathrm{CO}_{2}, 20^{\circ} \mathrm{C}+1000 \mathrm{ppm}$; HTLC, high temperature and low $\mathrm{CO}_{2}, 24^{\circ} \mathrm{C}+400 \mathrm{ppm}$; HTHC, high temperature and high $\mathrm{CO}_{2}, 24^{\circ} \mathrm{C}+1000 \mathrm{ppm}$ ) for 7 days in climate chambers (RXZ280A, Jiangnan Instrument Company, Ningbo, China), which control both the $p \mathrm{CO}_{2}$ concentration and temperature under the same relative humidity and light intensity conditions. In each acclimation treatment, approximately 100 limpets were randomly allocated into $\sim 30$ containers (three individuals in each container) to simulate field densities of $\sim 1$ limpet per $10 \mathrm{~cm}^{2}$. Control conditions $\left(20^{\circ} \mathrm{C}, 400 \mathrm{ppm}\right)$ represent the average annual temperature and ambient $p \mathrm{CO}_{2}(\sim 390 \mathrm{ppm})$ at the collection site, with high temperature $\left(24^{\circ} \mathrm{C}\right)$ and $p \mathrm{CO}_{2}(1000 \mathrm{ppm})$ representing the average global increase $\left(4^{\circ} \mathrm{C}, 600 \mathrm{ppm}\right)$ predicted for 2100 by the Intergovernmental Panel on Climate Change (IPCC, 2007).

Animals were kept in a simulated tidal cycle with $6 \mathrm{~h}$ of aerial exposure and $6 \mathrm{~h}$ of seawater immersion. Seawater was pre-bubbled with air containing the corresponding $p \mathrm{CO}_{2}$ concentrations in advance. The $\mathrm{pH}$ was measured before and after the acclimation in seawater each time with a PB-10 pH meter (Sartorius Instruments, Germany) calibrated with National Institute of Standards and Technology standard pH solutions (NIST, USA). Total dissolved inorganic carbon was measured before and after the acclimation in seawater each time using a dissolved inorganic carbon analyzer (As-C3, Apollo SciTech, Colorado, USA), using a Li-Cor ${ }^{\circledR}$ nondispersive infrared detector (Li-6252) with a precision of $0.1 \%$ (Cai, 2003). Seawater carbonate chemistry parameters were estimated based on the measured values of $\mathrm{pH}$, dissolved inorganic carbon, temperature, and salinity with the software CO2Calc v4.0.9 (Robbins et al., 2010). For CO2Calc settings, the NIST scale was applied as the $\mathrm{pH}$ scale, and the $\mathrm{CO}_{2}$ constant, the $\mathrm{KHSO}_{4}$-constant and the total boron were set from Millero et al. (2006), Dickson et al. (1990), and Lee et al. (2010), respectively. The information of the measured and calculated seawater chemistry parameters is summarized (Table 1).

After a 7-day acclimation period (crossed $p \mathrm{CO}_{2} \times$ temperature treatments, above), the heat-shock treatments were carried out to simulate the gradual temperature exposure of limpets in the field as described in Denny et al. (2006) (Fig. A1). For each heat-shock treatment, 10 limpets were randomly selected from each of four acclimation conditions (40 individual total) and transferred to artificial rocks (Fig. A2), with individuals from LTLC and LTHC on one rock and individuals from HTLC and HTHC on another rock. The artificial rocks were separately placed in $20^{\circ} \mathrm{C}$ water baths and $24^{\circ} \mathrm{C}$ water baths and heated at a rate of $6^{\circ} \mathrm{Ch}^{-1}$ that simulated emersion in the natural condition at the collection site (Han et al., 2013) to the designated temperatures $\left(26,30,34\right.$, and $\left.38^{\circ} \mathrm{C}\right)$. After achieving the target temperature, the temperature was maintained for the allotted time, and then decreased to the acclimation temperature (20 or $24^{\circ} \mathrm{C}$ ) at a rate of $6^{\circ} \mathrm{Ch}^{-1}$, for a total exposure time of $7 \mathrm{~h}$. Individuals from all four acclimation conditions $(n=10$ individuals per treatment) were randomly selected, transferred to artificial rocks, and aerially exposed at 20 or $24^{\circ} \mathrm{C}$ for $7 \mathrm{~h}$, as non-heated control samples. After recovery at 20 or $24^{\circ} \mathrm{C}$ seawater for $1 \mathrm{~h}$, limpets were immediately collected and stored at $-80^{\circ} \mathrm{C}$ for gene expression analysis.

\subsection{Cardiac performance measurement}

The cardiac performance of limpets was recorded during whole heating processes from the acclimated temperature (20 
Table 1. Measured and calculated seawater carbonate chemistry variables of each acclimation treatment during the experimental period*.

\begin{tabular}{lrrrr}
\hline & $20{ }^{\circ} \mathrm{C} \& 400 \mathrm{ppm}$ & $24{ }^{\circ} \mathrm{C} \& 400 \mathrm{ppm}$ & $20{ }^{\circ} \mathrm{C} \& 1000 \mathrm{ppm}$ & $24{ }^{\circ} \mathrm{C} \& 1000 \mathrm{ppm}$ \\
\hline Temperature $\left({ }^{\circ} \mathrm{C}\right)$ & $20.94 \pm 0.88$ & $24.84 \pm 0.87$ & $20.59 \pm 0.91$ & $25.01 \pm 0.67$ \\
Salinity $(\mathrm{psu})$ & $27.89 \pm 0.88$ & $27.96 \pm 0.75$ & $28.18 \pm 0.75$ & $27.79 \pm 0.58$ \\
$A_{\mathrm{T}}\left(\mu \mathrm{mol} \mathrm{kg}{ }^{-1}\right)$ & $2082.70 \pm 191.28$ & $2083.016 \pm 190.58$ & $2081.19 \pm 165.93$ & $2083.29 \pm 163.58$ \\
$\mathrm{DIC}\left(\mu \mathrm{mol} \mathrm{kg}^{-1}\right)$ & $1910.57 \pm 174.42$ & $1910.57 \pm 174.42$ & $1992.76 \pm 157.22$ & $1992.15 \pm 149.76$ \\
$p \mathrm{CO}_{2}(\mu \mathrm{tam})$ & $562.18 \pm 83.20$ & $561.81 \pm 83.04$ & $1008.66 \pm 113.41$ & $992.36 \pm 47.04$ \\
$\mathrm{pH}(\mathrm{NIST})$ & $8.05 \pm 0.05$ & $8.05 \pm 0.05$ & $7.82 \pm 0.04$ & $7.83 \pm 0.04$ \\
$\mathrm{CO}_{3}^{2-}\left(\mu \mathrm{mol} \mathrm{kg}{ }^{-1}\right)$ & $130.50 \pm 21.25$ & $130.64 \pm 20.85$ & $81.64 \pm 11.76$ & $83.42 \pm 11.95$ \\
$\Omega_{\mathrm{cal}}$ & $3.31 \pm 0.55$ & $3.32 \pm 0.54$ & $2.07 \pm 0.30$ & $2.12 \pm 0.30$ \\
\hline
\end{tabular}

* Seawater temperature, salinity, $\mathrm{pH}$, and total dissolved inorganic carbon ( $\left.\mathrm{DIC}_{\mathrm{T}}\right)$ were monitored every $6 \mathrm{~h}$. Total alkalinity $\left(A_{\mathrm{T}}\right), p \mathrm{CO}_{2}$, $\mathrm{CO}_{3}^{2-}$, and $\Omega_{\text {cal }}$ were calculated using CO2SYS software. Results were pooled and averaged over sampling times. Values are given as mean $\pm \mathrm{SD}$.

or $24^{\circ} \mathrm{C}$ ) to the temperature at which the heart stopped beating $(n=9-11$ individuals per acclimation treatment). Each limpet was placed in a separate container during the measurement. The containers were immersed in water baths, allowing the temperature in the container to be increased at a rate of $6^{\circ} \mathrm{Ch}^{-1}$ that simulated emersion in the natural environment. Heart rates were measured using a noninvasive method (Chelazzi et al., 2001; Dong and Williams, 2011). The heartbeat was detected by means of an infrared sensor fixed with Blu Tack (Bostik, Staffordshire, UK) on the limpet shell at a position above the heart. Variations in the light-dependent current produced by the heartbeat were amplified, filtered, and recorded using an infrared signal amplifier (AMP03, Newshift, Leiria, Portugal) and Powerlab AD converter (4/30, ADInstruments, March-Hugstetten, Germany). Data were viewed and analyzed using Lab Chart (version 7.0).

For determining the ABT of heart rate, discontinuities in the slopes of heart rate with temperature were calculated from intersections of fitted two-phase regressions based on the minimum sum of squares using SigmaPlot 12.5 (SSPS Inc., Point Richmond, CA, USA) as described by Giomi and Pörtner (2013).

\subsection{Quantifying gene expression}

Limpets were first taken out from $-80^{\circ} \mathrm{C}$; the foot muscle was cut off immediately using RNA-free scissors $\left(180^{\circ} \mathrm{C}\right.$ before using); the muscle ( $\sim 50 \mathrm{mg}$ ) was cut into pieces in a $1.5 \mathrm{~mL}$ EP tube containing RNA lysis buffer provided by Eastep reagent kit (Promega, USA); total RNA was isolated using Eastep reagent kit (Promega, USA). The first strand of cDNA was synthesized using total RNA as a template. Reverse transcriptase reactions were performed using a PrimeScript reverse transcriptase reagent kit with gDNA Eraser (Takara, Shiga, Japan).

The levels of mRNA of genes encoding two heat-hock proteins, inducible heat-shock protein 70 ( $h s p 70)$ and constitutive heat-shock protein 70 ( $h s c 70$ ), were measured us- ing real-time quantitative polymerase chain reactions in a CFX96 ${ }^{\mathrm{TM}}$ Real-Time System (Bio-Rad Laboratories, Inc., Hercules CA, USA) following the methods described by Han et al. (2013) with specific primers (Table A1). For normalizing expression of genes, we examined expression of the $18 \mathrm{~S}$ ribosomal RNA, $\beta$-actin, and $\beta$-tubulin genes, which typically have relatively stable expression levels. The expression stability of these housekeeping genes was evaluated using the geNorm algorithm (Primer Design, Ltd., Southampton University, Highfield Campus, Southampton Hants, UK) as described by Etschmann et al. (2006). Based on the expression stability measures ( $M$ values), all three genes were selected as the reference genes for normalizing the level of expression of stress-induced genes. All samples were measured in triplicates. $\mathrm{Ct}(\mathrm{dR})$ values were analyzed using the $\mathrm{CFX}$ Manager $^{\mathrm{TM}}$ software version 3.0 (Bio-Rad). The expression of $h s p 70$ and $h s c 70$ was determined relative to the value of $18 S, \beta$-actin, and $\beta$-tubulin from a reference individual.

\subsection{Statistical analysis}

The general additive mixed model (GAMM) was used to compare thermal sensitivities of heart rate among limpets acclimated at different temperatures $\left(20\right.$ or $\left.24^{\circ} \mathrm{C}\right)$ and $\mathrm{CO}_{2}$ concentrations (400 or $1000 \mathrm{ppm}$ ). Analyses were conducted with the mgcv (Wood, 2004) and nlme (Pinheiro et al., 2013) libraries in R Version 3.0 (R Core Team, 2014). The generalized additive model (GAM), describing heart rate as a function of temperature, was used to test for how heart rates of limpets from each treatment deviated from those of limpets from control conditions $\left(20^{\circ} \mathrm{C}, 400 \mathrm{ppm}\right)$ (Angilletta et al., 2013).

Thermal sensitivity is the change in a physiological rate function reacting to a rapid change in environmental temperature within the same acclimation set temperature (Fig. A3, modified from Seebacher et al., 2015). In the present study, thermal sensitivity was determined in the temperature coefficient $\left(Q_{10}\right)$ values of heart rate. $Q_{10}$ was calculated using heart rate data from the temperature at which the experiment 
started $\left(T_{1}=24^{\circ} \mathrm{C}\right)$ to the temperature to which temperature increased, $10^{\circ} \mathrm{C}\left(T_{2}=33^{\circ} \mathrm{C}\right)$, with Eq. (1):

$Q_{10}=\left(\frac{R_{2}}{R_{1}}\right)^{\frac{10}{T_{2}-T_{1}}}$,

where $R$ is the heart rate $\left(R_{1}\right.$ and $R_{2}$ are the heart rate at $T_{1}$ and $T_{2}$, respectively), and $T$ is the temperature (Kelvin) (Fig. A3, modified from Seebacher et al., 2015). The differences in $Q_{10}$ among the four acclimation conditions with different $\mathrm{CO}_{2}$ concentrations (400 ppm vs. $1000 \mathrm{ppm}$ ) and temperatures $\left(20^{\circ} \mathrm{C}\right.$ vs. $\left.24^{\circ} \mathrm{C}\right)$ were analyzed using two-way ANOVA with Duncan's post hoc analysis using the SPSS 20.0 for Windows statistical package (IBM SPSS Statistics, Chicago, USA). Post-acclimation thermal sensitivity of limpets in different $\mathrm{CO}_{2}$ concentrations was calculated as described by Seebacher et al. (2015). In each $\mathrm{CO}_{2}$ concentration (400 or $1000 \mathrm{ppm}$ ), the post-acclimation $Q_{10}$ values were calculated using the same equation as shown above, but $R_{2}$ was the average heart rate of the warm-acclimated limpets at the acclimated temperature $\left(T_{2}=24^{\circ} \mathrm{C}\right)$, and $R_{1}$ was the average heart rate of cold-acclimated limpets at $T_{1}=20^{\circ} \mathrm{C}$ (Fig. A3, modified from Seebacher et al., 2015). It is worth noting that post-acclimation thermal sensitivity should be considered with caution, as in the present study the acclimation period ( 7 days) may not have been sufficient for full acclimation to altered conditions.

The differences in levels of $h s p 70$ and $h s c 70$ among different heat-shock temperatures within a same acclimation condition were analyzed using one-way ANOVA with Duncan's post hoc analysis. The relationships between heat-shock temperature and log-transformed gene expression ( $h s p 70$ and $h s c 70)$ were fitted using linear regressions and the differences in slopes of the linear regressions were analyzed using analysis of covariance (ANCOVA).

The coefficient of variation (CV) of ABT, $Q_{10}$, and $h s c 70$ mRNA expression at $38^{\circ} \mathrm{C}$ were calculated for each acclimation condition. The $\mathrm{CV}$ is the variance in a sample divided by the mean of that sample, providing a method to compare the variation within a sample relative to the mean. It is generally accepted that higher $\mathrm{CV}$ demonstrates that there is greater variation among individuals within one treatment than another (Reed et al., 2002).

\section{Results}

\subsection{Cardiac performance}

The maximal heart rate was $\sim 30 \%$ higher in limpets acclimated to control conditions $\left(20^{\circ} \mathrm{C}, 400 \mathrm{ppm}\right)$ than the other treatments (Fig. 1 and Table A2). The ABTs of limpets showed a trend to be reduced for high-temperature treatments $\left(\right.$ mean $\pm \mathrm{SD}$ : LTLC, $38.9 \pm 2.9^{\circ} \mathrm{C}$; HTLC, $38.2 \pm 1.8^{\circ} \mathrm{C}$; LTHC, $40.0 \pm 3.3^{\circ} \mathrm{C}$; HTHC, $37.7 \pm 2.3^{\circ} \mathrm{C}$ ) (Fig. A4). Temperature (two-way ANOVA, $F_{1,35}=3.375, P=0.075$ ) and
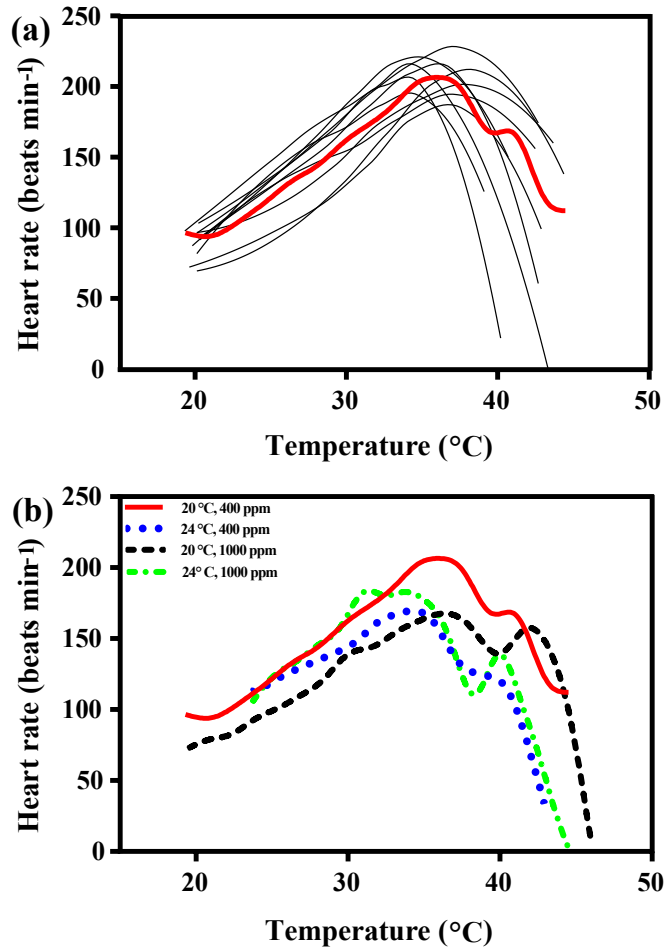

Figure 1. (a) Heart rates of all limpets acclimated to $20^{\circ} \mathrm{C}$ and $400 \mathrm{ppm}$, presented as an example of heart rate calculation for limpets in all treatments. The black lines correspond to smoothed fits (using the loess algorithm) of heart rates for each of the individual limpets. The red line represents the most likely general additive mixed model (GAMM) to depict the trajectory of heart rates for limpets with increasing temperature; (b) GAMM lines of limpets acclimated at the different experimental temperature and $\mathrm{CO}_{2}$ conditions.

$p \mathrm{CO}_{2}$ (two-way ANOVA, $F_{1,35}=0.118, P=0.733$ ) both had non-significant effects on ABTs, and there was a non-significant interaction between temperature and $p \mathrm{CO}_{2}$ (two-way ANOVA, $F_{1,35}=0.908, P=0.347$ ) (Table A3; Fig. A4).

Temperature coefficients $\left(Q_{10}\right.$ rates) were higher for limpets acclimated at $20^{\circ} \mathrm{C}$ than at $24^{\circ} \mathrm{C}$ (two-way ANOVA, $F_{1,35}=5.878, P=0.02$ ), but there was no significant difference for acclimation to different $p \mathrm{CO}_{2}$ concentrations (twoway ANOVA, $\left.F_{1,35}=1.332, P>0.05\right)$ and for the interaction between temperature and $p \mathrm{CO}_{2}$ (two-way ANOVA, $F_{1,35}=0.1135, P>0.05$ ) (Table A3; Fig. 2). The postacclimation thermal sensitivity of limpets acclimated at low $\mathrm{CO}_{2}$ (2.12) was lower than that of limpets at high $\mathrm{CO}_{2}$ (2.95) (Fig. 2).

The CVs of ABT in the four different acclimation conditions were different (Table 2). After low temperature and high $\mathrm{CO}_{2}$ acclimation (LTHC, 8.22\%), the CV of ABT was higher than that in the other three conditions (LTLC, $7.34 \%$; HTLC, $4.48 \%$; HTHC, $6.08 \%$ ). The CV of $Q_{10}$ under LTHC 
Table 2. Coefficients of variation (\%) of Arrhenius breakpoint temperature $(\mathrm{ABT})$, temperature coefficients $\left(Q_{10}\right)$, and $h s c 70$ mRNA expression at $38^{\circ} \mathrm{C}^{1,2}$.

\begin{tabular}{lrrrr}
\hline Temperature & $\mathrm{CO}_{2}$ & $\mathrm{ABT}$ & $Q_{10}$ & hsc70 mRNA \\
\hline 20 & 400 & 7.34 & 10.23 & 56.20 \\
& 1000 & 8.22 & 15.08 & 80.44 \\
24 & 400 & 4.48 & 10.08 & 80.12 \\
& 1000 & 6.08 & 11.82 & 90.36 \\
\hline
\end{tabular}

${ }^{1}$ Temperature coefficients $\left(Q_{10}\right)$ were calculated using heart rate from 24 to $33^{\circ} \mathrm{C} .{ }^{2}$ After acclimation at different $\mathrm{CO}_{2}$ and temperature for 1 week, limpets $(n=8-10)$ from each acclimation treatment were randomly selected and heat shocked at designated temperatures. Levels of $h s c 70$ mRNA at $38^{\circ} \mathrm{C}$ in different acclimation treatments were used for calculating coefficients of variation.

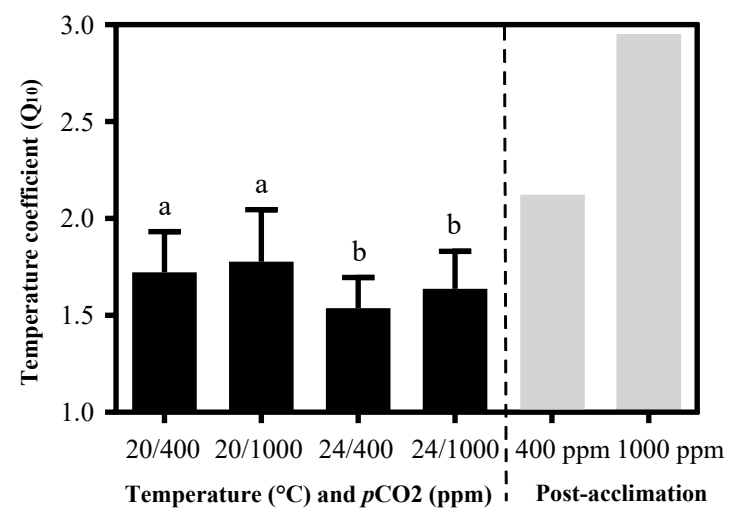

Figure 2. Temperature coefficients $\left(Q_{10}\right)$ of limpets acclimated at different temperatures $\left(20\right.$ or $24^{\circ} \mathrm{C}$ ) and $\mathrm{CO}_{2}$ concentrations $(400$ or $1000 \mathrm{ppm})$. The temperature coefficient $\left(Q_{10}\right)$ values were calculated for all limpets using heart rate data from 24 to $33^{\circ} \mathrm{C}$. Postacclimation temperature sensitivity was calculated among individuals acclimated at 20 and $24{ }^{\circ} \mathrm{C}$ (grey bars; sensu Seebacher et al., 2015) for each $\mathrm{CO}_{2}$ concentration, where higher thermal sensitivity indicates less acclimation to thermal stress. The calculation of post-acclimation $Q_{10}$ is carried out for the mean response of all individuals as the same individuals are not used at each acclimation temperature. Therefore, it is not possible to calculate an estimate of variation or error for post-acclimation $Q_{10}$. Different letters represent significant differences in the $Q_{10}$ among different acclimation treatments.

conditions was the highest in all four acclimation conditions (Table 2).

\subsection{Gene expression}

Levels of $h s p 70$ mRNA (log transformed) linearly increased with the increasing heat-shock temperatures (Fig. 3). ANCOVA showed that the slopes of the linear regressions were significantly different among different acclimation conditions $\left(F_{4,189}=42.62, P<0.001\right)$, and the slope of HTHC conditions was higher than that of the other three acclimation conditions. Thus, the rate of increase in production of $h s p 70$
mRNA in response to warming was greater at the elevated $\mathrm{CO}_{2}$ concentration.

The responses of $h s c 70$ mRNA to heat shock were divergent among the four acclimation conditions (Fig. 4). For HTHC limpets, there were no significant differences among different heat-shock temperatures $\left(F_{4,42}=2.11, P=0.096\right)$. For LTLC, LTHC, and HTLC limpets, levels of $h s c 70 \mathrm{mRNA}$ after being heat-shocked at $38^{\circ} \mathrm{C}$ were higher than corresponding levels of $h s c 70$ mRNA at 20 or $24{ }^{\circ} \mathrm{C}$ (Duncan's post hoc analysis, $F_{4,42}=4.389, P=0.005 ; F_{4,44}=8.521$, $\left.P<0.0001 ; F_{4,42}=5.713, P=0.001\right)$. The coefficients of variation of hsc mRNA after heat shock of $38^{\circ} \mathrm{C}$ were different among different acclimation conditions: HTHC $(90.36 \%)>\operatorname{LTHC} \quad(80.44 \%) \approx$ HCLT $\quad(80.12 \%)>$ LCLT $(56.20 \%)$ (Table 2).

\section{Discussion}

Short-term acclimation at elevated temperature and $p \mathrm{CO}_{2}$ can increase physiological sensitivity of limpets to thermal stress. The higher thermal sensitivity of limpets acclimated to $1000 \mathrm{ppm}$ indicates that the resilience of limpets to thermal stress associated with warming will be compromised under future ocean acidification. This prediction is contrary to the general thought that intertidal ectotherms, such as limpets and other gastropods, will demonstrate high tolerance to thermal stress because they are adapted to an extreme thermal environment. For example, the operative temperatures, which C. toreuma suffers under in the field, frequently exceed $40^{\circ} \mathrm{C}$ in summer along Asian coastlines and the limpet can survive at temperatures in excess of $45^{\circ} \mathrm{C}$ (Dong et al., 2015). Our data show, however, that ocean acidification will lead to increased sensitivity to changes to future thermal regimes, indicating a synergistic negative effect. The change in the metabolic partitioning in individuals could ultimately lead to a decline in fitness and population-level responses in the future.

Increased temperature and $\mathrm{CO}_{2}$ elevated the sensitivity of heat-shock responses to thermal stress. The expression of inducible $h s p 70$ mRNA steadily increased from 20 to $38^{\circ} \mathrm{C}$ for individuals across all experimental treatments. However, rates of upregulation of $h s p 70$ mRNA in limpets acclimated at high temperature and high $\mathrm{CO}_{2}$ (HTHC) were significantly higher than that of limpets acclimated at the other three acclimation conditions. As a molecular chaperone, Hsp70 protein plays crucial roles in maintaining protein stability with the expense of a large amount of energy (Feder and Hofmann, 1999; Tomanek and Sanford, 2003). By comparing the expression patterns of Hsp70 of different Chlorostoma species (formerly Tegula) that have distinct vertical distributions, Tomanek and Somero $(1999,2000)$ found that there were interspecific differences in the frequency of the induction of Hsp70 synthesis and interspecific divergence of the time course of Hsp70 synthesis. These studies from the genus 

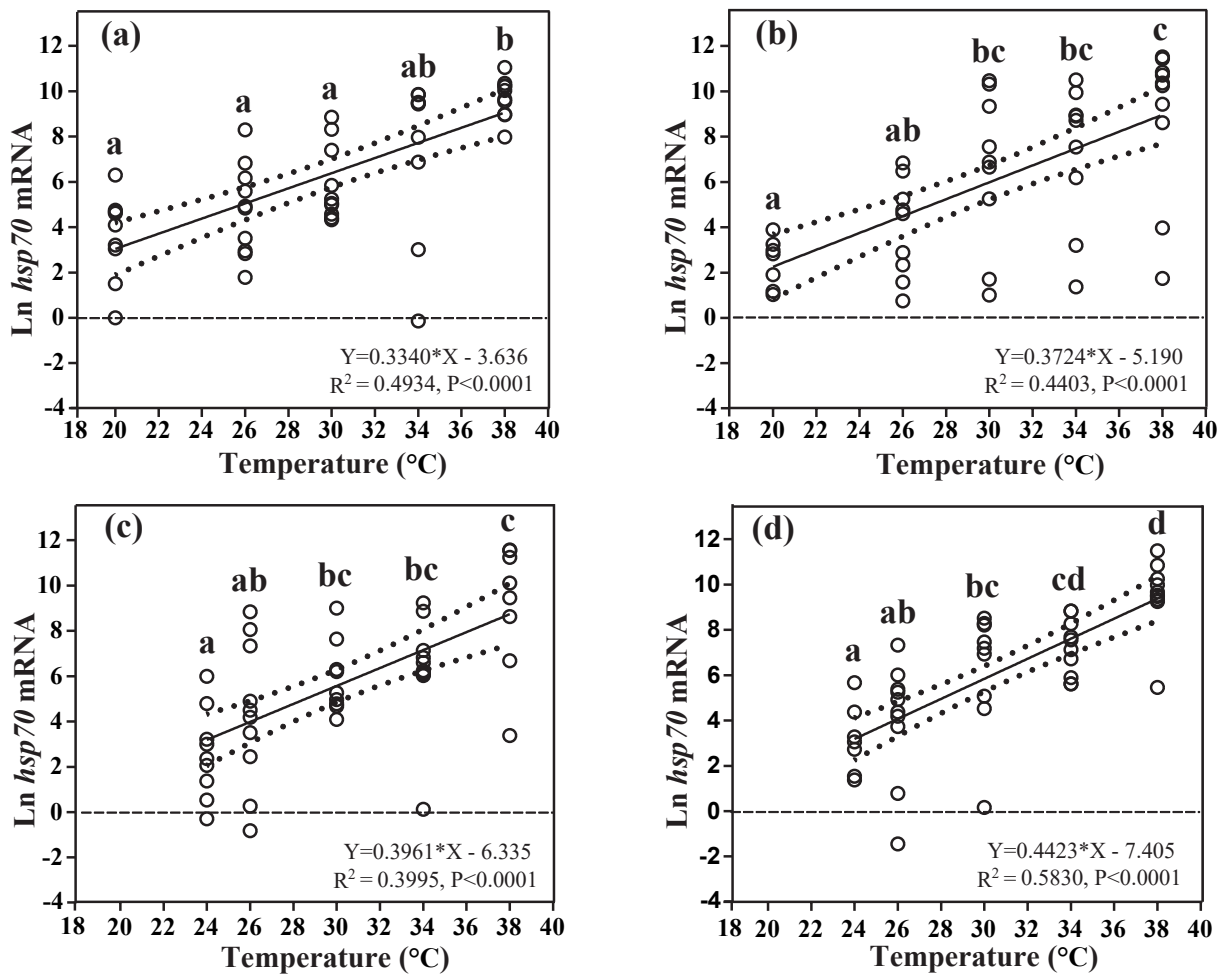

Figure 3. Effects of heat-shock temperature on the expression of $h s p 70 \mathrm{mRNA}$ in limpets acclimated at (a) $20^{\circ} \mathrm{C}$ and $400 \mathrm{ppm}$, (b) $20^{\circ} \mathrm{C}$ and $1000 \mathrm{ppm}$, (c) $24^{\circ} \mathrm{C}$ and $400 \mathrm{ppm}$, and (d) $24^{\circ} \mathrm{C}$ and $1000 \mathrm{ppm}$. The relationship between heat-shock temperature and log-transformed gene expression of $h s p 70$ was fitted using linear regressions with $95 \%$ confidence intervals (dashed lines). Different letters represent significant differences in the level of $h s p 70$ mRNA among different heat-shock temperatures.

Chlorostoma suggested that species that live higher in the intertidal zone spend more energy for proteostasis and restoring proteostasis to cope with a second consecutive day of high temperatures (Somero et al., 2016). Usually, the expression of Hsp70 of less thermal-tolerant species is more sensitive to increases in temperature (limpet Lottia, Dong et al., 2008; snail Chlorostoma, Tomanek, 2002), and the rapid upregulation of $h s p 70 \mathrm{mRNA}$ in limpets exposed to future conditions potentially represents a high sensitivity of limpets to thermal stress in the face of ocean acidification. Due to the expensive energy consumption during the synthesis and function of $h s p 70$, the more rapid upregulation of hsp70 mRNA in these limpets also indicates more energy was allocated into cellular homeostasis, which then can affect the growth and reproduction of limpets.

The expression patterns of constitutive $h s c 70$ mRNA were different among limpets acclimated at the four acclimation conditions. Hsc70 is constitutively expressed and is a molecular chaperone involved in the in vivo folding and repair of denatured proteins (Dong et al., 2015). Although $h s p 70$ and hsc 70 contain similar promoter regions, there are differential expressions to a given stimulus between them (Hansen et al., 1991). Some studies showed that thermal stress could significantly induce the upregulation of both the $h s c 70$ gene and
Hsc70 protein in the killifish Fundulus heteroclitus (Fangue et al., 2006), the shrimp Penaeus monodon (Chuang et al., 2007), and the coral Veretillum cynomorium (Teixeira et al., 2013). In the present study, for limpets acclimated under HTLC and LTHC (i.e., only temperature or $\mathrm{CO}_{2}$ condition changed in comparison with the LTLC treatment), there was significant upregulation of $h s c 70 \mathrm{mRNA}$ when the heatshock temperatures were beyond $30^{\circ} \mathrm{C}$. However, the expression of $h s c 70$ mRNA showed no significant difference among different heat-shock temperatures under predicated future environmental conditions (HTHC: $24^{\circ} \mathrm{C}$ and $1000 \mathrm{ppm}$ ). These results indicate that the upregulation of $h s c 70$ mRNA in response to heat shock represents an increasing capability for coping with the enhanced protein denaturation and more energy allocated into the somatic maintenance after being exposed to either warming or a high- $\mathrm{CO}_{2}$ environment. The insignificant upregulation of $h s c 70$ in response to thermal stress indicates that limpets acclimated under HTHC may employ a "preparative defense" strategy (Dong et al., 2008) to maintain high constitutive levels of $h s c 70$ as a mechanism to cope with unpredictable heat stress. However, the absence of significant upregulation of $h s c 70$ mRNA in limpets acclimated to future conditions (warming and elevated $\mathrm{CO}_{2}$ ) might also be attributed to the very high variation in gene ex- 

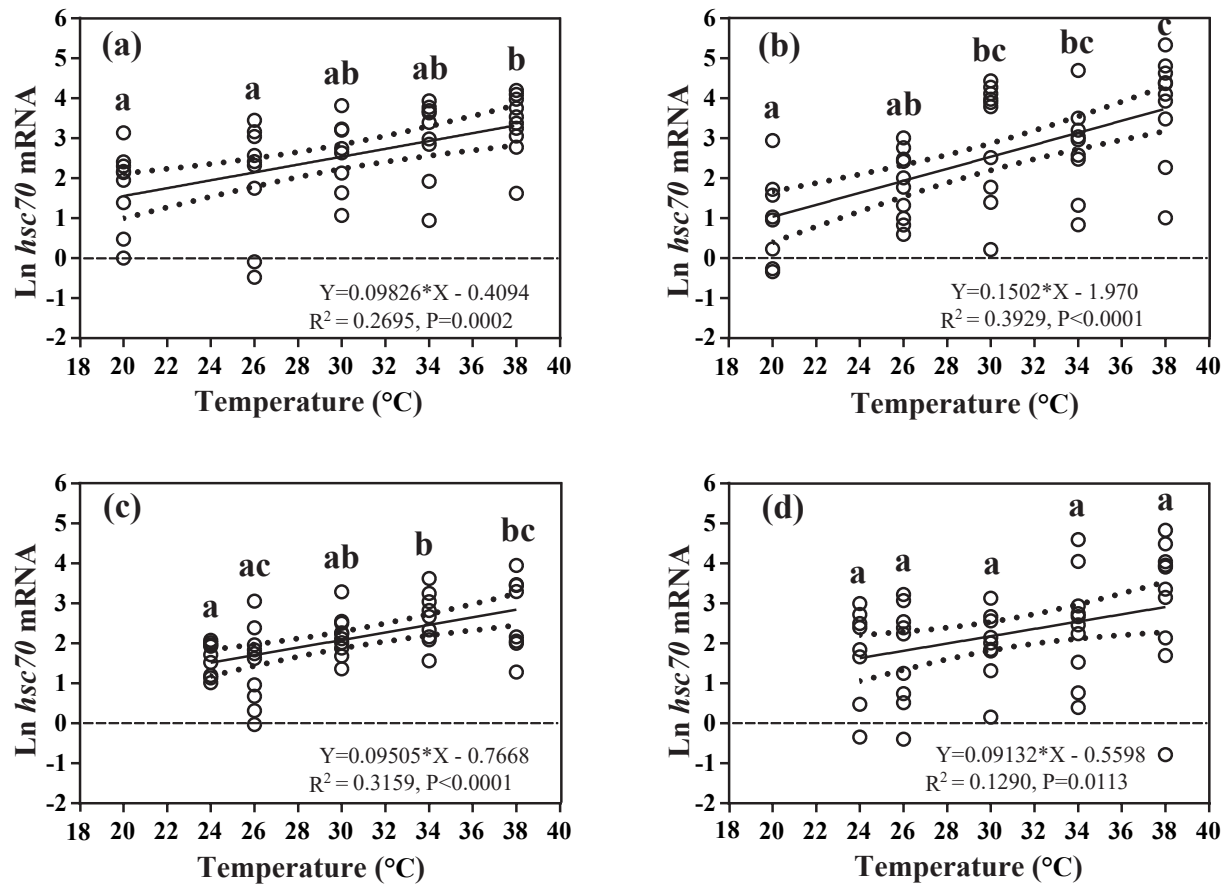

Figure 4. Effects of heat-shock temperature on the expression of $h s c 70 \mathrm{mRNA}$ in limpets acclimated at (a) $20^{\circ} \mathrm{C}$ and $400 \mathrm{ppm}$, (b) $20^{\circ} \mathrm{C}$ and $1000 \mathrm{ppm}$, (c) $24^{\circ} \mathrm{C}$ and $400 \mathrm{ppm}$, and (d) $24^{\circ} \mathrm{C}$ and $1000 \mathrm{ppm}$. The relationship between heat-shock temperature and log-transformed gene expression of $h s c 70$ was fitted using linear regressions with $95 \%$ confidence intervals (dahs lines). Different letters represent significant differences in the level of $h s c 70$ mRNA among different heat-shock temperatures.

pression at $38^{\circ} \mathrm{C}(\mathrm{CV}, 90.36 \%)$. In the context of future conditions, multiple environmental stressors can induce diverse physiological responses among different individuals, which might be an evolutionary adaptation to the harsh environment on the shore.

Variation and plasticity in both physiological and molecular responses to thermal stress are not only important for coping with future environmental changes but also underpin evolutionary and adaptive changes through selective pressures (Franks and Hoffmann, 2012). In the present study, the coefficients of variation in physiological responses of limpets acclimated to simulated future conditions, including ABT, $Q_{10}$, and $h s c 70 \mathrm{mRNA}$, were higher than that in the other three acclimation conditions. Crucially, this means that a subset of individuals in our experimental population might be more physiologically preadapted to cope with heat shock. Once acclimated to a future climate change scenario (warming and ocean acidification), this variation in physiological performance increased, indicating that in a harsher environment the physiological plasticity of some individuals allows them to modify their physiological tolerance limits and increase chances for survival and reproduction (Williams et al., 2008). Under high selective pressure, these individuals would form the basis for future generations while less-plastic individuals would be removed from populations. However, differences among the coefficients of variation need to be in- terpreted with caution, as multiple factors can cause this type of variation, including the variable environmental history of individuals despite a 7-day acclimation, competition among individuals during the acclimation period, or the sample size (around 10 limpets per treatment).

Intertidal limpets may experience two sorts of stressful temperature exposures in the field, abrupt or gradual exposure (Denny et al., 2006). The present study showed the upregulation of $h s p 70$ and $h s c 70$ expression in C. toreuma under gradual exposure. Similar expression patterns have also been observed in Hsp70 under gradual thermal exposure in other intertidal limpets (Dong et al., 2008; Miller et al., 2009). Importantly, the gradual experimental change in thermal environment used here mimics conditions that most intertidal species experience in the field and is important for predicting how animals will resolve prolonged aerial exposure during low tide. Conversely, experimentally simulating abrupt thermal change helps us understand physiological responses to some extreme conditions, such as heat wave (upregulation of $h s p 70$ in intertidal limpets; Prusina et al., 2014). Therefore, future work combining both abrupt and gradual exposure may offer insight into how intertidal species respond to climate change and extreme weather events in the future. Further, since our findings are based on static experimental conditions, the results should be treated with caution when we predict the response of an organism to future 
climate change in the highly variable natural environment. Therefore, future studies with long-term acclimation, larger sample size, and variable treatment conditions are recommended in order to validate our findings.

In conclusion, the resilience of intertidal limpets to thermal stress is weakened after exposure to predicted future conditions for a short-term acclimation period (7 days). However, the combination of elevated temperature and $\mathrm{CO}_{2}$ concentration prompted divergence of physiological and molecular responses. These results suggest that while organisms may be able to protect themselves from the damaging effects of thermal stress in the short term, changes to multiple environmental conditions may drive population-level responses through physiological responses (e.g., Giomi et al., 2016). Further, the increased variation in responses, and the observation that some individuals were more capable to physiologically cope with the conditions, may be associated with intergenerational adaptation, but this speculation needs further evidence. As the "weaker" individuals are lost, the offspring in the next generation will be better physiologically adapted to warming under high- $\mathrm{CO}_{2}$ conditions. Therefore, while elevated $\mathrm{CO}_{2}$ and the associated ocean acidification decrease the ability of many individuals to respond to thermal stress, it appears that physiological plasticity and variability could be adaptive mechanisms in at least some populations of intertidal organisms. Our research underlines the importance of physiological plasticity and variability for coastal species coping with warming and ocean acidification.

Data availability. All data associated with this paper can be found at the designated Dryad depository (https://doi.org/10.5061/dryad.7s3m38n; Wang et al., 2018). 


\section{Appendix A}

Table A1. Functions and primers of selected genes of the Cellana limpet.

\begin{tabular}{|c|c|c|c|}
\hline Gene name & Gene symbol & Function & Primers $\left(5^{\prime}-3^{\prime}\right)$ \\
\hline Heat-shock cognate $71 \mathrm{kDa}$ protein & hsc 70 & molecular chaperone & $\begin{array}{l}\text { F: CCTGAATGTGTCCGCTGTG } \\
\text { R: TTCCTGTCTTCCTCGCTGAT }\end{array}$ \\
\hline Heat-shock protein 70 & hsp 70 & molecular chaperone & $\begin{array}{l}\text { F: CAACACCTTCACGACTTA } \\
\text { R: CCACAGCAGATACATTCA }\end{array}$ \\
\hline Beta-actin & $\beta$-actin & reference gene & $\begin{array}{l}\text { F: AGGTATTGCCGACAGAATG } \\
\text { R: TTGGAAGGTGGACAGAGA }\end{array}$ \\
\hline Tubulin beta chain & $\beta$-tubulin & reference gene & $\begin{array}{l}\text { F: AGGTGCTGAATTGGTAGAC } \\
\text { R: TTGCTGATGAGGAGAGTTC }\end{array}$ \\
\hline 18S ribosomal RNA & $18 s$ & reference gene & $\begin{array}{l}\text { F: ATAGCCTATATCGGAGTT } \\
\text { R: ATGGATACATCAAGGTTAT }\end{array}$ \\
\hline
\end{tabular}

Table A2. Inferential statistics for the most likely general additive mixed models (GAMMs) of heart rate during continuous warming of the limpet Cellana toreuma acclimated at different temperatures $\left(20 \text { and } 24^{\circ} \mathrm{C} \text { ) and } p \mathrm{CO}_{2} \text { levels (400 and } 1000 \mathrm{ppm}\right)^{*}$.

\begin{tabular}{lrrr}
\hline Effect & d.f. & $F$ & $P$ value \\
\hline$f(T)$ for $C$. toreuma from $20^{\circ} \mathrm{C}$ and $400 \mathrm{ppm}$ & 18.46 & 191.2 & $<0.001$ \\
\hline Deviation from $f(T)$ for $C$. toreuma from $20^{\circ} \mathrm{C}$ and $1000 \mathrm{ppm}$ & 17.2 & 25.018 & $<0.001$ \\
Deviation from $f(T)$ for $C$. toreuma from $24^{\circ} \mathrm{C}$ and $400 \mathrm{ppm}$ & 16.157 & 65.328 & $<0.001$ \\
Deviation from $f(T)$ for $C$. toreuma from $24^{\circ} \mathrm{C}$ and $1000 \mathrm{ppm}$ & 20.194 & 41.634 & $<0.001$ \\
\hline$f(T)$ for $C$. toreuma from $20^{\circ} \mathrm{C}$ and $1000 \mathrm{ppm}$ & 18.75 & 135 & $<0.001$ \\
\hline Deviation from $f(T)$ for $C$. toreuma from $24^{\circ} \mathrm{C}$ and $400 \mathrm{ppm}$ & 10.502 & 42.441 & $<0.001$ \\
Deviation from $f(T)$ for $C$. toreuma from $24^{\circ} \mathrm{C}$ and $1000 \mathrm{ppm}$ & 19.753 & 40.229 & $<0.001$ \\
\hline$f(T)$ for $C$. toreuma from $24^{\circ} \mathrm{C}$ and $400 \mathrm{ppm}$ & 13.3 & 35.58 & $<0.001$ \\
\hline Deviation from $f(T)$ for $C$. toreuma from $24^{\circ} \mathrm{C}$ and $1000 \mathrm{ppm}$ & 13.337 & 6.364 & $<0.001$ \\
\hline$f(T)$ for $C$. toreuma from $24^{\circ} \mathrm{C}$ and $1000 \mathrm{ppm}$ & 18.35 & 52.54 & $<0.001$ \\
\hline
\end{tabular}

* The generalized additive model describes heart rate as a function of temperature, or $f(T)$, instead of using a fixed parameter to describe the effect of temperature. Additional functions were included to describe how heart rates of $C$. toreuma from each treatment deviated from those of C. toreuma from $20^{\circ} \mathrm{C}$ and $400 \mathrm{ppm}$. 
Table A3. Two-way ANOVA to investigate the effects of temperature $\left(20\right.$ and $\left.24^{\circ} \mathrm{C}\right)$ and $p \mathrm{CO}_{2}(400$ and $1000 \mathrm{ppm})$ on Arrhenius breakpoint temperature (ABT) of heart rate and temperature coefficients $\left(Q_{10}\right)$ on Cellana toreuma.

\begin{tabular}{lrrrrr}
\hline Source of variation & DF & SS & MS & $F$ & $P$ \\
\hline Two-way ANOVA for ABT & & & & \\
\hline Temperature & 1 & 22.580 & 22.580 & 3.375 & 0.075 \\
$p \mathrm{CO}_{2}$ & 1 & 0.790 & 0.790 & 0.118 & 0.733 \\
Temperature $\times p \mathrm{CO}_{2}$ & 1 & 6.076 & 6.076 & 0.908 & 0.347 \\
Residual & 35 & 234.200 & 6.692 & & \\
\hline Two-way ANOVA for $Q_{10}$ & & & & \\
\hline Temperature & 1 & 0.257 & 0.257 & 5.878 & 0.021 \\
$p \mathrm{CO}_{2}$ & 1 & 0.058 & 0.058 & 1.332 & 0.256 \\
Temperature $\times p \mathrm{CO}_{2}$ & 1 & 0.005 & 0.005 & 0.1135 & 0.738 \\
Residual & 35 & 1.527 & 0.0436 & & \\
\hline
\end{tabular}
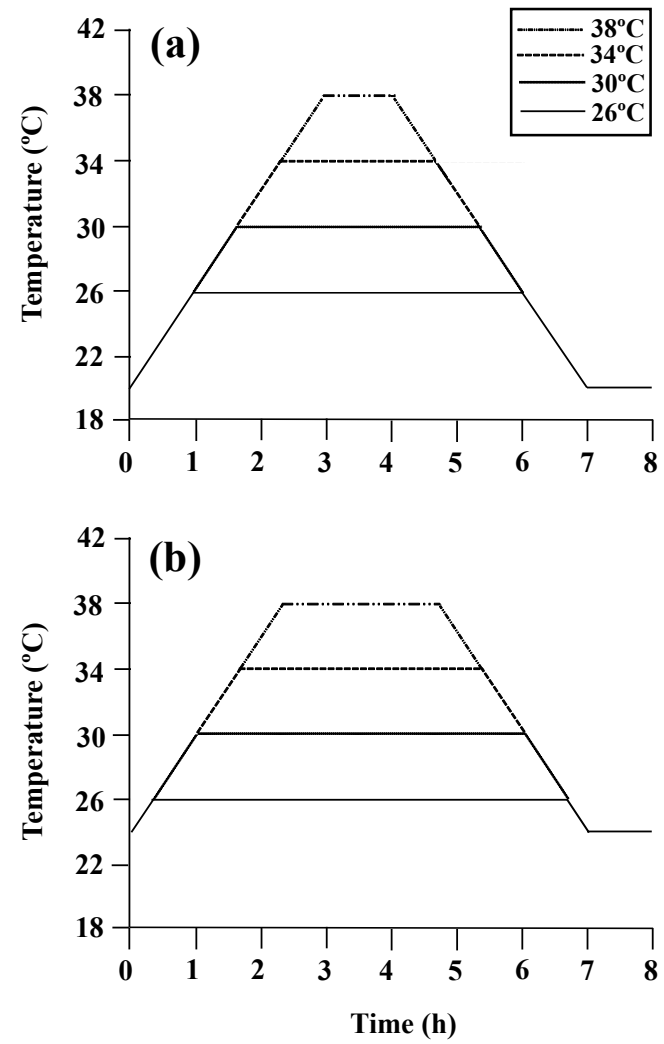

Figure A1. Diagram of the heating protocol for (a) limpets acclimated at $20^{\circ} \mathrm{C}$ and (b) limpets acclimated at $24^{\circ} \mathrm{C}$. Limpets were heated at a rate of $6^{\circ} \mathrm{Ch}^{-1}$ from acclimation temperatures (20 or $\left.24^{\circ} \mathrm{C}\right)$ to designated temperatures $\left(26,30,34\right.$, and $\left.38^{\circ} \mathrm{C}\right)$ for simulating a natural heating rate in summer. After achieving the target temperature, the temperature was held at the designated level for the allotted time and then decreased to acclimated temperatures ( 20 or $24^{\circ} \mathrm{C}$ ) at a rate of $6^{\circ} \mathrm{Ch}^{-1}$, for a total exposure time of $7 \mathrm{~h}$. After recovery in 20 or $24^{\circ} \mathrm{C}$ seawater for $1 \mathrm{~h}$, limpets $(n=8-10)$ in each treatment were immediately collected and stored at $-80^{\circ} \mathrm{C}$ for gene expression measurement.

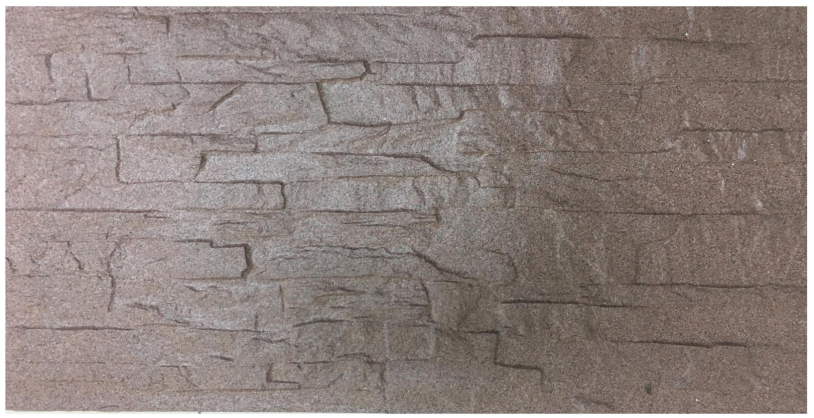

Figure A2. The photo of artificial rock $(60 \mathrm{~cm}$ length $\times 30 \mathrm{~cm}$ width). Limpets were placed on artificial rock and heated to the designated temperate. 


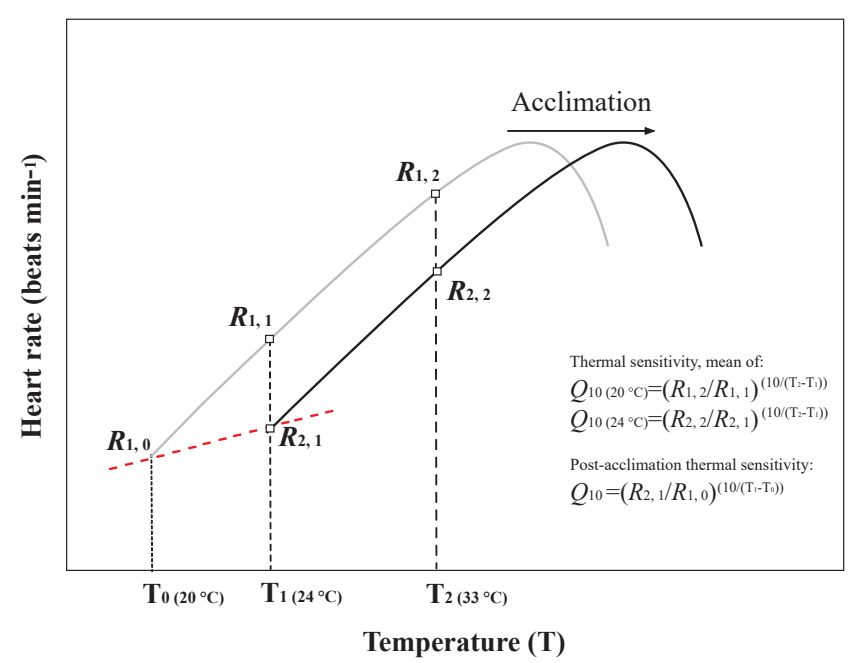

Figure A3. Schematic diagram of temperature coefficients $\left(Q_{10}\right)$ and post-acclimation $Q_{10}$ calculations. This figure was modified from Seebacher et al. (2015). The black line and grey line showed the heart rate of limpets from the warm-acclimated temperature $\left(24^{\circ} \mathrm{C}\right)$ and the cold-acclimated temperature $\left(20^{\circ} \mathrm{C}\right)$, respectively. $Q_{10}$ values for thermal sensitivities were calculated from data for limpets kept at an acclimation treatment in which heart rate was measured at two different temperatures. $Q_{10}$ value for postacclimation thermal sensitivities was calculated across two temperature acclimation conditions under the same $p \mathrm{CO}_{2}$ condition.

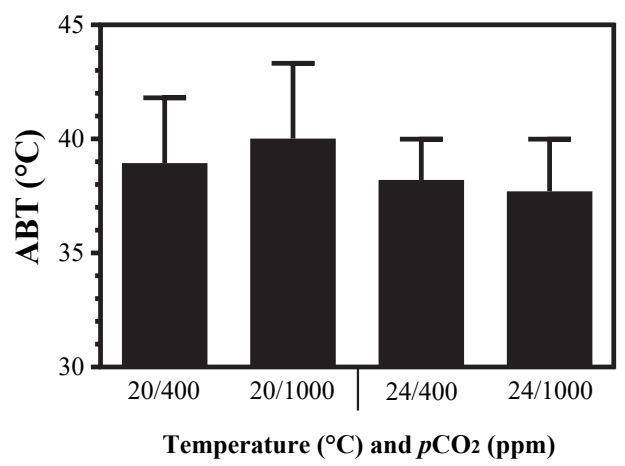

Figure A4. Arrhenius breakpoint temperature $(\mathrm{ABT})$ of heart rate of limpets acclimated at different temperatures $\left(20\right.$ or $\left.24^{\circ} \mathrm{C}\right)$ and $\mathrm{CO}_{2}$ concentrations (400 or $1000 \mathrm{ppm}$ ). After acclimation in different conditions, limpets were heated continuously from acclimation temperatures until the heart stopped beating. During the heating process, heart rates were recorded and ABTs were calculated. 
Author contributions. BDR and YWD designed the experiments. WJ and MWD conducted the experiments. YWD, BDR, WJ, and MWD performed analyses. The paper was co-written by YWD, WJ, and MWD and revised by BDR.

Competing interests. The authors declare that they have no conflict of interest.

Acknowledgements. This work was supported by grants from the National Natural Science Foundation of China (41476115, 41776135), Nature Science funds for Distinguished Young Scholars of Fujian Province, China (2017J07003), Program for New Century Excellent Talents of Ministry of Education, China, and the State Key laboratory of Marine Environmental Science visiting fellowship to Bayden D. Russell.

Edited by: Carol Robinson

Reviewed by: Maria Byrne, Stephen J. Hawkins, and two anonymous referees

\section{References}

Angilletta, M. J., Zelic, M. H., Adrian, G. J., Hurliman, A. M., and Smith, C. D.: Heat tolerance during embryonic development has not diverged among populations of a widespread species (Sceloporus undulatus), Conserv. Physiol., 1, cot018, https://doi.org/10.1093/conphys/cot018, 2013.

Bao, B. and Ren, G. Y.: Climatological characteristics and longterm change of SST over the marginal seas of China, Cont. Shelf Res., 77, 96-106, https://doi.org/10.1016/j.csr.2014.01.013, 2014.

Braby, C. E. and Somero, G. N.: Following the heart: temperature and salinity effects on heart rate in native and invasive species of blue mussels (genus Mytilus), J. Exp. Biol., 209, 2554-2566, https://doi.org/10.1242/jeb.02259, 2006.

Byrne, M.: Impact of ocean warming and ocean acidification on marine invertebrate life history stages: vulnerabilities and potential for persistence in a changing ocean, Oceanogr. Mar. Biol., 49, 1-42, https://doi.org/10.1201/b11009-2, 2011.

Byrne, M. and Przeslawski, R.: Multistressor impacts of warming and acidification of the ocean on marine invertebrates' life histories, Integr. Comp. Biol., 53, 582-596, https://doi.org/10.1093/icb/ict049, 2013.

Cai, M., Liu, Y., Chen, K., Huang, D., and Yang, S.: Quantitative analysis of anthropogenic influences on coastal water-A new perspective, Ecol. Indic., 67, 673-683, https://doi.org/10.1016/j.ecolind.2016.07.041, 2016.

Cai, W. J.: Riverine inorganic carbon flux and rate of biological uptake in the Mississippi River plume, Geophys. Res. Lett., 30, 1032, https://doi.org/10.1029/2002g1016312, 2003.

Chelazzi, G., De Pirro, M., and Williams, G. A.: Cardiac responses to abiotic factors in two tropical limpets, occurring at different levels of the shore, Mar. Biol., 139, 1079-1085, https://doi.org/10.1007/s002270100603, 2001.

Chevin, L. M., Lande, R., and Mace, G. M.: Adaptation, plasticity, and extinction in a changing environment: towards a predictive theory, PLoS Biol., 8, e1000357, https://doi.org/10.1371/journal.pbio.1000357, 2010.

Chuang, K. H., Ho, S. H., and Song, Y. L.: Cloning and expression analysis of heat shock cognate 70 gene promoter in tiger shrimp (Penaeus monodon), Gene, 405, 10-18, https://doi.org/10.1016/j.gene.2007.08.016, 2007.

Denny, M. W., Miller, L. P., and Harley, C. D.: Thermal stress on intertidal limpets: long-term hindcasts and lethal limits, J. Exp. Biol., 209, 2420-2431, https://doi.org/10.1242/jeb.02258, 2006.

Deutsch, C., Ferrel, A., Seibel, B., Portner, H. O., and Huey, R. B.: Climate change tightens a metabolic constraint on marine habitats, Science, 348, 1132-1135, https://doi.org/10.1126/science.aaa1605, 2015.

Dickson, A. G.: Standard potential of the reaction: $\mathrm{AgCl}(\mathrm{s})+\mathrm{H} 2(\mathrm{~g})$ $=\mathrm{Ag}(\mathrm{s})+\mathrm{HCl}(\mathrm{aq})$, and the standard acidity constant of the ion HSO4-in synthetic sea water from 273.15 to $318.15 \mathrm{~K}$, J. Chem. Thermodyn., 22, 113-127, https://doi.org/10.1016/00219614(90)90074-z, 1990.

Ding, M. W., Wang, Z. K., and Dong, Y. W.: Food availability on the shore: Linking epilithic and planktonic microalgae to the food ingested by two intertidal gastropods, Mar. Environ. Res., 136, 71-77, https://doi.org/10.1016/j.marenvres.2018.02.005, 2018.

Dong, Y. W. and Williams, G. A.: Variations in cardiac performance and heat shock protein expression to thermal stress in two differently zoned limpets on a tropical rocky shore, Mar. Biol., 158, 1223-1231, https://doi.org/10.1007/s00227-011-1642-6, 2011.

Dong, Y. W., Miller, L. P., Sanders, J. G., and Somero, G. N.: Heatshock protein 70 (Hsp70) expression in four limpets of the genus Lottia: interspecific variation in constitutive and inducible synthesis correlates with in situ exposure to heat stress, Biol. Bull., 215, 173-181, https://doi.org/10.2307/25470698, 2008.

Dong, Y. W., Wang, H. S., Han, G. D., Ke, C. H., Zhan, X., Nakano, T., and Williams, G. A.: The impact of Yangtze River discharge, ocean currents and historical events on the biogeographic pattern of Cellana toreuma along the China coast, PLoS One, 7, e36178, https://doi.org/10.1371/journal.pone.0036178, 2012.

Dong, Y. W., Han, G. D., and Huang, X. W.: Stress modulation of cellular metabolic sensors: interaction of stress from temperature and rainfall on the intertidal limpet Cellana toreuma, Mol. Ecol., 23, 4541-4554, https://doi.org/10.1111/mec.12882, 2014.

Dong, Y. W., Han, G. D., Ganmanee, M., and Wang, J.: Latitudinal variability of physiological responses to heat stress of the intertidal limpet Cellana toreuma along the Asian coast, Mar. Ecol.Prog. Ser., 529, 107-119, https://doi.org/10.3354/meps11303, 2015.

Dong, Y. W., Li, X. X., Choi, F. M., Williams, G. A., Somero, G. N., and Helmuth, B.: Untangling the roles of microclimate, behaviour and physiological polymorphism in governing vulnerability of intertidal snails to heat stress, P. R. Soc. B., 284, 20162367, https://doi.org/10.1098/rspb.2016.2367, 2017.

Etschmann, B., Wilcken, B., Stoevesand, K., von der Schulenburg, A., and Sterner-Kock, A.: Selection of reference genes for quantitative real-time PCR analysis in canine mammary tumors using the GeNorm algorithm, Vet. Pathol., 43, 934-942, https://doi.org/10.1354/vp.43-6-934, 2006.

Fabricius, K. E., Langdon, C., Uthicke, S., Humphrey, C., Noonan, S., De'ath, G., Okazaki, R., Muehllehner, N., Glas, M. S., and Lough, J. M.: Losers and winners in coral reefs acclimatized to 
elevated carbon dioxide concentrations, Nat. Clim. Change, 1, 165-169, https://doi.org/10.1038/nclimate1122, 2011.

Fabry, V. J., Seibel, B. A., Feely, R. A., and Orr, J. C.: Impacts of ocean acidification on marine fauna and ecosystem processes, ICES J. Mar. Sci., 65, 414-432, https://doi.org/10.1093/icesjms/fsn048, 2008.

Fangue, N. A., Hofmeister, M., and Schulte, P. M.: Intraspecific variation in thermal tolerance and heat shock protein gene expression in common killifish, Fundulus heteroclitus, J. Exp. Biol., 209, 2859-2872, https://doi.org/10.1242/jeb.02260, 2006.

Feder, M. E. and Hofmann, G. E.: Heat-shock proteins, molecular chaperones, and the stress response: evolutionary and ecological physiology, Annu. Rev. Physiol., 61, 243-282, https://doi.org/10.1146/annurev.physiol.61.1.243, 1999.

Firth, L. B. and Williams, G. A.: The influence of multiple environmental stressors on the limpet Cellana toreuma during the summer monsoon season in Hong Kong, J. Exp. Mar. Biol. Ecol., 375, 70-75, https://doi.org/10.1016/j.jembe.2009.05.011, 2009.

Franks, S. J. and Hoffmann, A. A.: Genetics of climate change adaptation, Annu. Rev. Genet., 46, 185-208, https://doi.org/10.1146/annurev-genet-110711-155511, 2012.

Giomi, F. and Poertner, H. O.: A role for haemolymph oxygen capacity in heat tolerance of eurythermal crabs, Front. Physiol., 4, 110, https://doi.org/10.3389/fphys.2013.00110, 2013.

Giomi, F., Mandaglio, C., Ganmanee, M., Han, G. D., Dong, Y. W., Williams, G. A., and Sara, G.: The importance of thermal history: costs and benefits of heat exposure in a tropical, rocky shore oyster, J. Exp. Biol., 219, 686-694, https://doi.org/10.1242/jeb.128892, 2016.

Gooding, R. A., Harley, C. D., and Tang, E.: Elevated water temperature and carbon dioxide concentration increase the growth of a keystone echinoderm, P. Natl. Acad. Sci. USA, 106, 9316-9321, https://doi.org/10.1073/pnas.0811143106, 2009.

Han, G. D., Zhang, S., Marshall, D. J., Ke, C. H., and Dong, Y. W.: Metabolic energy sensors (AMPK and SIRT1), protein carbonylation and cardiac failure as biomarkers of thermal stress in an intertidal limpet: linking energetic allocation with environmental temperature during aerial emersion, J. Exp. Biol., 216, 32733282, https://doi.org/10.1242/jeb.084269, 2013.

Hansen, L. K., Houchins, J. P., and O'Leary, J. J.: Differential regulation of HSC70, HSP70, HSP90 alpha, and HSP90 beta mRNA expression by mitogen activation and heat shock in human lymphocytes, Exp. Cell. Res., 192, 587-596, https://doi.org/10.1016/0014-4827(91)90080-e, 1991.

Helmuth, B., Mieszkowska, N., Moore, P., and Hawkins, S. J.: Living on the edge of two changing worlds: forecasting the responses of rocky intertidal ecosystems to climate change, Annu. Rev. Ecol. Evol. Syst., 37, 373404, https://doi.org/10.1146/annurev.ecolsys.37.091305.110149, 2006.

Hoegh-Guldberg, O., Mumby, P. J., Hooten, A. J., Steneck, R. S., Greenfield, P., Gomez, E., Harvell, C. D., Sale, P. F., Edwards, A. J., Caldeira, K., Knowlton, N., Eakin, C. M., Iglesias-Prieto, R., Muthiga, N., Bradbury, R. H., Dubi, A., and Hatziolos, M. E.: Coral reefs under rapid climate change and ocean acidification, Science, 318, 1737-1742, https://doi.org/10.1126/science.1152509, 2007.
Hoffmann, A. A. and Sgro, C. M.: Climate change and evolutionary adaptation, Nature, 470, 479-485, https://doi.org/10.1038/nature09670, 2011.

Hofmann, G. E. and Todgham, A. E.: Living in the now: physiological mechanisms to tolerate a rapidly changing environment, Annu. Rev. Physiol., 72, 127-145, https://doi.org/10.1146/annurev-physiol-021909-135900, 2010.

IPCC: Climate change 2007: The physical science basis, in: Working group I contribution to the fourth assessment report of the IPCC, edited by: Solomon, S., Cambridge Uni. Press, New York, 2007.

IPCC: Climate change 2013: The physical science basis, in: Working Group I Contribution to the Fifth Assessment Report of the Intergovernmental Panel on Clilmate Change, edited by: Stocker, T. F., Qin, D., Plattner, G.-K., Tignor, M., Allen, S. K., Boschung, J., Nauels, A., Xia, Y., Bex, V., and Midgley, P. M., Cambridge Univ. Press, New York, 2013.

Kroeker, K. J., Kordas, R. L., Crim, R., Hendriks, I. E., Ramajo, L., Singh, G. S., Duarte, G. M., and Gattuso, J. P.: Impacts of ocean acidification on marine organisms: quantifying sensitivities and interaction with warming, Glob. Change Biol., 19, 1884-1896, https://doi.org/10.1111/gcb.12179, 2013.

Kwiatkowski, L., Gaylord, B., Hill, T., Hosfelt, J., Kroeker, K. J., Nebuchina, Y., Ninokawa, A., Russell, A. D., Rivest, E. B., and Sesboüé, M.: Nighttime dissolution in a temperate coastal ocean ecosystem increases under acidification, Sci. Rep., 6, 22984 , https://doi.org/10.1038/srep22984, 2016.

Lathlean, J. and Seuront, L.: Infrared thermography in marine ecology: methods, previous applications and future challenges, Mar. Ecol.-Prog. Ser., 514, 263-277, https://doi.org/10.3354/meps10995, 2014.

Lee, K., Kim, T. W., Byrne, R. H., Millero, F. J., Feely, R. A., and Liu, Y. M.: The universal ratio of boron to chlorinity for the North Pacific and North Atlantic oceans, Geochim. Cosmochim. Ac., 74, 1801-1811, https://doi.org/10.1016/j.gca.2009.12.027, 2010.

Miller, L. P., Harley, C. D., and Denny, M. W.: The role of temperature and desiccation stress in limiting the local-scale distribution of the owl limpet, Lottia gigantea, Funct. Ecol., 23, 756-767, https://doi.org/10.1111/j.1365-2435.2009.01567.x, 2009.

Millero, F. J., Graham, T. B., Huang, F., Bustos-Serrano, H., and Pierrot, D.: Dissociation constants of carbonic acid in seawater as a function of salinity and temperature, Mar. Chem., 100, 8094, https://doi.org/10.1016/j.marchem.2005.12.001, 2006.

Morton, B. S. and Morton, J. E.: The seashore ecology of Hong Kong, Hong Kong University Press, Hong Kong, 1983.

Munday, P. L., Crawley, N. E., and Nilsson, G. E.: Interacting effects of elevated temperature and ocean acidification on the aerobic performance of coral reef fishes, Mar. Ecol.-Prog. Ser., 388, 235-242, https://doi.org/10.3354/meps08137, 2009.

Nickerson, D. M., Facey, D. E., and Grossman, G. D.: Estimating physiological thresholds with continuous two-phase regression, Physiol. Zool., 62, 866-887, https://doi.org/10.1086/physzool.62.4.30157934, 1989.

Oleksiak, M. F., Churchill, G. A., and Crawford, D. L.: Variation in gene expression within and among natural populations, Nat. Genet., 32, 261-266, https://doi.org/10.1038/ng983, 2002. 
Parmesan, C. and Yohe, G.: A globally coherent fingerprint of climate change impacts across natural systems, Nature, 421, 37-42, https://doi.org/10.1038/nature01286, 2003.

Pinheiro, J., Bates, D., DebRoy, S., Sarkar, D., Heisterkamp, S., Van Willigen, B., and Maintainer, R.: Package "nlme", R package version 3, 2013.

Pörtner, H. O.: Integrating climate-related stressor effects on marine organisms: unifying principles linking molecule to ecosystem-level changes, Mar. Ecol.-Prog. Ser., 470, 273-290, https://doi.org/10.3354/meps10123, 2012.

Prosser, C. L.: Physiological Variation in Animals, Biol. Rev., 30, 229-261, https://doi.org/10.1111/j.1469-185x.1955.tb01208.x, 1955.

Prusina, I., Sarà, G., De Pirro, M., Dong, Y. W., Han, G. D., Glamuzina, B., and Williams, G. A.: Variations in physiological responses to thermal stress in congeneric limpets in the Mediterranean Sea, J. Exp. Mar. Biol. Ecol., 456, 34-40, https://doi.org/10.1016/j.jembe.2014.03.011, 2014.

R Core Team: R: A language and environment for statistical computing, Vienna, Austria: R Foundation for Statistical Computing, 2014.

Reed, G. F., Lynn, F., and Meade, B. D.: Use of coefficient of variation in assessing variability of quantitative assays, Clin. Diagn. Lab. Immun., 9, 1235-1239, https://doi.org/10.1128/cdli.10.6.1162.2003, 2002.

Robbins, L. L., Hansen, M. E., Kleypas, J. A., and Meylan, S. C.: CO2calc: A user-friendly seawater carbon calculator for Windows, Mac OS X, and iOS (iPhone), US Geological Survey, 2010.

Rodolfo-Metalpa, R., Houlbreque, F., Tambutte, E., Boisson, F., Baggini, C., Patti, F. P., Jeffree, R., Fine, M., Foggo, A., Gattuso, J. P., and Hall-Spencer, J. M.: Coral and mollusc resistance to ocean acidification adversely affected by warming, Nat. Clim. Change, 1, 308-312, https://doi.org/10.1038/nclimate1200, 2011.

Ruppert, E. E., Fox, R. D., Ruppert, R. S., Fox, R. S., and Barnes, R. D.: Invertebrate zoology: a functional evolutionary approach, No. 592 RUPi, https://doi.org/10.1080/10635150490472977, 2004.

Sanford, E. and Kelly, M. W.: Local adaptation in marine invertebrates, Annu. Rev. Mar. Sci., 3, 509-535, https://doi.org/10.1146/annurev-marine-120709-142756, 2011.

Sconzo, G., Palla, F., Agueli, C., Spinelli, G., Giudice, G., Cascino, D., and Geraci, F.: Constitutive hsp70 is essential to mitosis during early cleavage of Paracentrotus lividus embryos: the blockage of constitutive hsp70 impairs mitosis, Biochem. Bioph. Res. Co., 260, 143-149, https://doi.org/10.1006/bbrc.1999.0782, 1999.

Seebacher, F., White, C. R., and Franklin, C. E.: Physiological plasticity increases resilience of ectothermic animals to climate change, Nat. Clim. Change, 5, 61-66, https://doi.org/10.1038/nclimate2457, 2015.

Sokolova, I. M. and Berger, V. J.: Physiological variation related to shell colour polymorphism in White Sea Littorina saxatilis, J. Exp. Mar. Biol. Ecol., 245, 1-23, https://doi.org/10.1016/s00220981(99)00132-x, 2000.
Somero, G. N.: Thermal physiology and vertical zonation of intertidal animals: optima, limits, and costs of living, Integr. Comp. Biol., 42, 780-789, https://doi.org/10.1093/icb/42.4.780, 2002.

Somero, G. N.: The physiology of global change: linking patterns to mechanisms, Annu. Rev. Mar. Sci., 4, 39-61, https://doi.org/10.1146/annurev-marine-120710-100935, 2012.

Somero, G. N., Lockwood, B. L., and Tomanek, L.: Biochemical adaptation: response to environmental challenges, from life's origins to the Anthropocene, Oxford University Press, Oxford, UK, 2016.

Teixeira, T., Diniz, M., Calado, R., and Rosa, R.: Coral physiological adaptations to air exposure: heat shock and oxidative stress responses in Veretillum cynomorium, J. Exp. Mar. Biol. Ecol., 439, 35-41, https://doi.org/10.1016/j.jembe.2012.10.010, 2013.

Tomanek, L.: The heat-shock response: its variation, regulation and ecological importance in intertidal gastropods (genus Tegula), Integr. Comp. Biol., 42, 797-807, https://doi.org/10.1093/icb/42.4.797, 2002.

Tomanek, L. and Sanford, E.: Heat-shock protein 70 (Hsp70) as a biochemical stress indicator: An experimental field test in two congeneric intertidal gastropods (Genus: Tegula), Biol. Bull., 205, 276-284, https://doi.org/10.2307/1543291, 2003.

Tomanek, L. and Somero, G. N.: Evolutionary and acclimationinduced variation in the heat-shock responses of congeneric marine snails (genus Tegula) from different thermal habitats: implications for limits of thermotolerance and biogeography, J. Exp. Biol., 202, 2925-2936, https://doi.org/10.1016/s10956433(99)90421-x, 1999.

Tomanek, L. and Somero, G. N.: Time course and magnitude of synthesis of heat-shock proteins in congeneric marine snails (genus Tegula) from different tidal heights, Physiol. Biochem. Zool., 73, 249-256, https://doi.org/10.1086/316740, 2000.

Wang, J., Russell, B. D., Ding, M. W., and Dong, Y. W.: Ocean acidification increases the sensitivity of and variability in physiological responses of an intertidal limpet to thermal stress, https://doi.org/10.5061/dryad.7s3m38n, 2018.

Widdicombe, S. and Spicer, J. I.: Predicting the impact of ocean acidification on benthic biodiversity: what can animal physiology tell us?, J. Exp. Mar. Biol. Ecol., 366, 187-197, https://doi.org/10.1016/j.jembe.2008.07.024, 2008.

Williams, S. E., Shoo, L. P., Isaac, J. L., Hoffmann, A. A., and Langham, G.: Towards an integrated framework for assessing the vulnerability of species to climate change, PLoS Biol., 6, 26212626, https://doi.org/10.1371/journal.pbio.0060325, 2008.

Wood, S.: mgcv: GAMs with GCV smoothness estimation and GAMMs by REML/PQL, R package version 1, 2004.

Xing, Q., Li, Y. P., Guo, H. B., Yu, Q., Huang, X. T., Wang, S., Hu, X. L., Zhang, L. L., and Bao, Z. M.: Cardiac performance: a thermal tolerance indicator in scallops, Mar. Biol., 163, 1-9, https://doi.org/10.1007/s00227-016-3021-9, 2016.

Yan, X. H., Cai, R. S., and Bai, Y. S.: Long-term change of the marine environment and plankton in the Xiamen Sea under the influence of climate change and human sewage, Toxicol. Environ. Chem., 98, 669-678, https://doi.org/10.1080/02772248.2015.1133376, 2016. 